\title{
4-Phenylbutyric acid improves free fatty acid-induced hepatic insulin resistance in vivo
}

\author{
Sandra Pereira', Jessy Moore ${ }^{2}$, Jia-Xu Li ${ }^{3}$, Wen Qin Yu' ${ }^{1}$, Husam Ghanim ${ }^{4}$, Filip Vlavcheski ${ }^{2}$, Yemisi Deborah Joseph ${ }^{1}$, \\ Paresh Dandona ${ }^{4}$, Allen Volchuk ${ }^{1,5}$, Carolyn L Cummins ${ }^{3}$, Evangelia Tsiani ${ }^{2}$ and Adria Giacca ${ }^{1,6,7,8}$ \\ ${ }^{1}$ Department of Physiology, University of Toronto, Toronto, Ontario, Canada \\ 2Department of Health Sciences, Brock University, St. Catharines, Ontario, Canada \\ ${ }^{3}$ Department of Pharmaceutical Sciences, University of Toronto, Toronto, Ontario, Canada \\ ${ }^{4}$ Division of Endocrinology, Diabetes, and Metabolism, State University of New York at Buffalo, Kaleida Health, Buffalo, New York, USA \\ ${ }^{5}$ Division of Cellular and Molecular Biology, Toronto General Research Institute, University Health Network, Toronto, Ontario, Canada \\ ${ }^{6}$ Department of Medicine, University of Toronto, Toronto, Ontario, Canada \\ ${ }^{7}$ Institute of Medical Science, University of Toronto, Toronto, Ontario, Canada \\ ${ }^{8}$ Banting and Best Diabetes Centre, University of Toronto, Toronto, Ontario, Canada
}

Correspondence should be addressed to A Giacca: adria.giacca@utoronto.ca

\begin{abstract}
Plasma free fatty acids (FFAs) are elevated in obesity and can induce insulin resistance via endoplasmic reticulum (ER) stress. However, it is unknown whether hepatic insulin resistance caused by the elevation of plasma FFAs is alleviated by chemical chaperones. Rats received one of the following i.v. treatments for $48 \mathrm{~h}$ : saline, intralipid plus heparin $(\mathrm{IH}), \mathrm{IH}$ plus the chemical chaperone 4-phenylbutyric acid (PBA), or PBA alone and a hyperinsulinemic-euglycemic clamp was performed during the last $2 \mathrm{~h}$. PBA co-infusion normalized $\mathrm{IH}$-induced peripheral insulin resistance, similar to our previous findings with an antioxidant and an IxB $\alpha$ kinase $\beta$ (IKK $\beta$ ) inhibitor. Different from our previous results with the antioxidant and IKK $\beta$ inhibitor, PBA also improved IH-induced hepatic insulin resistance in parallel with activation of Akt. Unexpectedly, IH did not induce markers of ER stress in the liver, but PBA prevented IH-induced elevation of phosphorylated eukaryotic initiation factor-2 $\alpha$ protein in adipose tissue. PBA tended to decrease circulating fetuin-A and significantly increased circulating fibroblast growth factor 21 (FGF21) without affecting markers of activation of hepatic protein kinase C- $\delta$ or p38 mitogen-activated protein kinase that we have previously involved in hepatic insulin resistance in this model. In conclusion: (i) PBA prevented hepatic insulin resistance caused by prolonged plasma FFA elevation without affecting hepatic ER stress markers; (ii) the PBA effect is likely due to increased FGF21 and/or decreased fetuin-A, which directly signal to upregulate Akt activation.
\end{abstract}

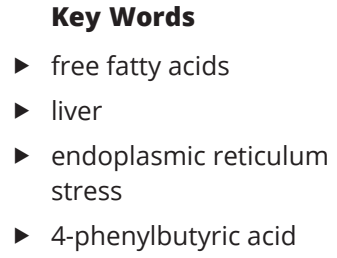

\section{Introduction}

Obesity is characterized by elevated circulating free fatty acids (FFAs) that cause insulin resistance in the liver and periphery $(1,2)$. FFAs induce endoplasmic reticulum (ER) stress, which occurs when misfolded or unfolded proteins amass in the ER, and ER stress causes insulin resistance $(3,4$, 5). High-fat diet is widely used to induce insulin resistance, but it does not allow to assess the selective effect of FFAs. In order to determine the effect of FFAs per se on insulin sensitivity in vivo, investigators have used i.v. infusions of fatty acids (in rodents) or lipid emulsions (in rodents and humans). In rodents, short-term infusions of oleate elevating plasma FFAs by two-fold induced hepatic ER stress, as evidenced by an elevation in markers of unfolded protein response activation in the liver (6).

Chemical chaperones that reduced ER stress, such as 4-phenylbutyric acid (PBA) and taurine-conjugated

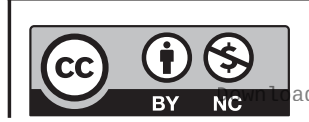

This work is licensed under a Creative Commons Attribution-NonCommercial 4.0 International License. ded from Bioscientifica.com at 04/26/2023 07:14:24AM 
ursodeoxycholic acid (TUDCA), have been used in rodent and human studies to alleviate insulin resistance. PBA and TUDCA improve insulin sensitivity in the liver and periphery, including muscle and adipose tissue, of $o b / o b$ mice (7). Similarly, $d b / d b$ mice treated with PBA show a reduction in the hepatic expression of gluconeogenic enzymes (8). In obese humans, TUDCA increases hepatic and peripheral insulin sensitivity (9).

Our collaborative studies in humans show that PBA partially prevents whole-body insulin resistance induced by prolonged $(48 \mathrm{~h}$ ) infusion of intralipid, a soy oil emulsion rich in $\omega-6$ polyunsaturated fatty acids (PUFAs), plus heparin (IH) (10). However, it remained to be investigated whether PBA acted as a chemical chaperone to reduce ER stress in this model since PBA has pleiotropic effects, including its property to inhibit histone deacetylases (11). Furthermore, it was not assessed whether PBA prevented hepatic insulin resistance and if this was due to alleviation of hepatic ER stress. In rats, where liver tissue collection is feasible, we have found that neither N-acetyl-L-cysteine (NAC), an antioxidant, nor salicylate, an IxB $\alpha$ kinase $\beta$ (IKK $\beta$ ) inhibitor, prevents hepatic insulin resistance caused by $48 \mathrm{~h}$ IH infusion $(12,13)$. Thus, the objective of the current study was to determine whether PBA could prevent induction of hepatic insulin resistance in this rat model and if this was due to alleviation of hepatic ER stress.

\section{Materials and methods}

\section{Experimental design}

Experiments were approved by the Animal Care Committee of the University of Toronto and followed the Canadian Council of Animal Care standards. Female animals were studied as in our previous work with NAC and salicylate $(12,13)$. Female Wistar rats $(250-300 \mathrm{~g})$ were ordered from Charles River (Saint-Constant, QC, Canada) and kept in the Department of Comparative Medicine at the University of Toronto. Animals had access to standard chow (Teklad Global Diet \#2018 from Harlan Laboratories, Indianapolis, IN, USA) and water ad libitum. Following approximately 7-14 days of acclimatization, the jugular vein and carotid artery were cannulated, and the catheters were externalized under isoflurane anesthesia (13). Animals recovered from surgery for at least 3 days before experiments were initiated. On the first day of the experiment, the infusion and sampling lines were prepared as described (13). Rats were randomized into the following i.v. treatment groups: SAL (Saline; $5.5 \mu \mathrm{L} / \mathrm{min}$ ), IH (20\% intralipid plus $20 \mathrm{U} / \mathrm{mL}$ heparin; $5.5 \mu \mathrm{L} / \mathrm{min})$, IH plus PBA $(2.08 \mu \mathrm{mol} / \mathrm{kg} / \mathrm{min}$; Sigma-Aldrich), or PBA. IH infusion is a selective model of plasma FFA elevation without adiposity as abdominal fat pad weight was not significantly altered $(7.9 \pm 1.5 \mathrm{~g}$ in SAL group vs $7.9 \pm 0.8 \mathrm{~g}$ in IH group; $n=3$ /group).

Treatments were infused via the jugular vein while blood samples were obtained from the carotid artery. The treatment infusion lasted $48 \mathrm{~h}$. For each treatment, two types of studies were performed in different rats: a basal infusion study and an infusion study followed by a hyperinsulinemic-euglycemic clamp. An overnight fast was started on the second experiment day for both types of studies. In the basal infusion study, the treatment was infused for $48 \mathrm{~h}$ and this was followed by plasma and tissue collection on the third experiment day. In the clamp study, a primed infusion of $\left[3{ }^{3} \mathrm{H}\right]$ glucose $(8 \mu \mathrm{Ci}$ bolus, then 0.15 $\mu \mathrm{Ci} / \mathrm{min})$ was initiated at $44 \mathrm{~h}$ ( $2 \mathrm{~h}$ before the clamp) to assess basal glucose kinetics and was continued throughout the clamp to distinguish between hepatic and peripheral insulin sensitivity, as previously described (13). The $2 \mathrm{~h}$ hyperinsulinemic ( $5 \mathrm{mU} / \mathrm{kg} / \mathrm{min})$ euglycemic clamp was carried out during the last $2 \mathrm{~h}$ of treatment infusion (13). The glucose infusion required to maintain constant plasma glucose was radiolabelled to also maintain glucosespecific activity constant as previously reported (13). In the clamp study, there are two steady states: the basal steady state, which corresponds to the last $30 \mathrm{~min}$ before the start of insulin infusion, and the clamp steady state, which corresponds to the last $30 \mathrm{~min}$ of the hyperinsulinemiceuglycemic clamp. During each steady state, every $10 \mathrm{~min}$ blood samples were collected to measure plasma glucose, FFAs, insulin, and $\left[3-{ }^{3} \mathrm{H}\right]$ glucose specific activity (13). At the end of both basal and clamp experiments, rats were anesthetized, the liver was freeze-clamped, and retroperitoneal adipose tissue as well as soleus muscle were collected. Tissues were stored at $-80^{\circ} \mathrm{C}$ until the time of analysis.

Results for glucose kinetics as well as the corresponding plasma insulin and FFA concentrations for SAL and $\mathrm{IH}$ experiments used in this manuscript have been previously reported in the Journal of Endocrinology (12) (copyright permission is not required as the journal has the same publisher). The experiments reported in that paper were done at the same time as those with PBA reported here.

\section{Plasma assays}

Determination of glucose kinetics involved deproteinization of plasma samples and quantification of

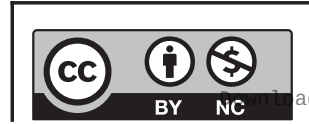

This work is licensed under a Creative Commons Attribution-NonCommercial 4.0 International License. ded from Bioscientifica.com at 04/26/2023 07:14:24AM 
radioactivity due to $\left[3-{ }^{3} \mathrm{H}\right]$ glucose in plasma as well as tracer and radiolabelled glucose infusates (13). A glucose analyzer was used to determine plasma glucose concentrations (12). An RIA was used to quantify the concentrations of insulin in plasma (Millipore) (13). A colorimetric assay from Wako Pure Chemical Industries, Ltd was utilized to measure plasma FFA concentrations (13). Plasma interleukin 6 (IL-6), fetuin-A, and fibroblast growth factor 21 (FGF21) were measured as previously reported (14); these plasma parameters were measured in plasma collected at the end of infusions during the basal state.

\section{Western blots}

Whole lysates of liver samples were obtained as previously described (13). Homogenization of adipose tissue samples was carried out utilizing one of the following lysis buffers: (i) a lysis buffer consisting of $250 \mathrm{mM}$ sucrose, 4 mM HEPES, 1 $\mathrm{mM} \mathrm{MgCl}_{2}$, pH7.4, $1 \mathrm{mM}$ PMSF, $10 \mathrm{mM} \mathrm{NaF}, 2 \mathrm{mM} \mathrm{Na}_{3} \mathrm{VO}_{4}$, $10 \mathrm{nM}$ okadaic acid, and protease inhibitors (Roche) or (ii) a lysis buffer consisting of $20 \mathrm{mM}$ Tris- $\mathrm{HCl}, 150 \mathrm{mM} \mathrm{NaCl}, 1$ mM EDTA, 1 mM EGTA, 1\% Triton X-100, $2.5 \mathrm{mM} \mathrm{Na}_{4} \mathrm{P}_{2} \mathrm{O}_{7}$, $1 \mathrm{mM}$ glycerol-2-phosphate, $1 \mathrm{mM} \mathrm{Na} \mathrm{NO}_{4}, 1 \mu \mathrm{g} / \mathrm{mL}$ leupeptin, and $1 \mathrm{mM}$ PMSF. Liver samples collected after 48 $\mathrm{h}$ basal infusion studies were separated into cytosolic and membranes fractions for protein kinase C (PKC)- $\delta$ Western blots (13); purity of membrane fractions was confirmed by probing for sodium-potassium ATPase protein. Soleus muscle was homogenized with a lysis buffer consisting of 50 $\mathrm{mM}$ Tris (pH 7.5), $150 \mathrm{mM} \mathrm{NaCl}, 1 \mathrm{mM} \mathrm{MgCl}_{2}, 1 \mathrm{mM} \mathrm{CaCl}_{2}$, $2 \mathrm{mM}$ EGTA, $10 \mathrm{mM} \mathrm{Na}_{4} \mathrm{P}_{2} \mathrm{O}_{7} \cdot 10 \mathrm{H}_{2} \mathrm{O}, 10 \mathrm{mM} \mathrm{NaF}, 10 \mu \mathrm{g} / \mathrm{mL}$ aprotinin, $10 \mu \mathrm{g} / \mathrm{mL}$ leupeptin, $50 \mathrm{nM}$ okadaic acid, $1 \mathrm{mM}$ PMSF, $1 \mathrm{mM} \mathrm{Na}_{3} \mathrm{VO}_{4}$, and 1\% NP-40 alternative. Western blot analysis was then performed $(13,15,16)$. All primary antibodies were from Cell Signaling Technology, except antibodies for FGF21 (Santa Cruz Biotechnology), $\beta$-actin (Santa Cruz), suppressor of cytokine signaling 3 (SOCS3; Thermo Fisher Scientific), and sodium-potassium ATPase (Abcam). p38 mitogen-activated protein kinase (MAPK) phosphorylates ATF2 on Thr71 and ATF7 on Thr53 (17); hence, we utilized an antibody that recognizes ATF2 and ATF7 when phosphorylated at these sites (p-ATF2/7; Cell Signaling Technology). Actin, tubulin, or glyceraldehyde3-phosphate dehydrogenase (GAPDH) was used as a loading control. Quantification of bands was done with ImageJ (National Institutes of Health, USA); when a given sample was run more than once for a specific parameter, quantification results were averaged for that sample.

\section{RT-PCR analysis}

Quantitative RT-PCR for glucose-regulated protein 78 (GRP78) mRNA in the liver and adipose tissue samples was carried out as detailed in Zhang et al. (15). Briefly, RNA was extracted using RNeasy Mini Kit (Qiagen), RT-PCR involved the use of TaqMan Gene Expression system and appropriate rat primers (Applied Biosystems), and results were analyzed with SDS 2.1 software. Quantitative RT-PCR for FGF21, IL-6, and fetuin-A mRNA was performed as described in Patel et al. (18). Primer sequences were: Fgf21, forward-5 'GTCCGACAGAGGTATCTCTACACAGATGA and reverse-5'GAGCTCCAGGAGACTTTCTGGACT; Il6, forward-5'TAGTCCTTCCTACСCСAATTTCC and reverse5'TTGGTCCTTAGCCACTCCTTC; Fetuin-A (Ahsg), forward-5'ACGTGGTCCACACTGTCAAA and reverse5'CGCAGCTATCACAAACTCCA; Beta-actin (Actb; housekeeping gene), forward-5'AAGTCCCTCACCCTC CCAAAAG and reverse-5'AAGCAATGCTGTCACCTTCCC.

\section{Oil red 0 staining}

Liver samples collected after $48 \mathrm{~h}$ basal infusion studies were stained with Oil Red O. The staining intensity was quantified in ImageJ.

\section{Calculations}

In the basal steady state, endogenous glucose production (EGP) equals glucose utilization $\left(\mathrm{R}_{\mathrm{d}}\right)$. In the clamp steady-state, EGP equals $R_{d}$ minus the exogenous glucose infusion rate. The calculations of glucose kinetics have been previously described (13). For a given parameter, the average of values during each steady state (basal period and last 30 min of clamp) was used.

\section{Statistical analysis}

Data are presented as mean+S.E.M. For parameters involving four treatment groups and two periods (basal and clamp), two-way ANOVA followed by Tukey's test was used. When comparing parameters across three or four treatment groups during a given period, one-way ANOVA with Tukey's test was performed. An unpaired $t$-test was used when comparing parameters between two treatment groups. Statistical analysis was done using GraphPad Prism 8 and significance was accepted if $P<0.05$.
This work is licensed under a Creative Commons Attribution-NonCommercial 4.0 International License. ded from Bioscientifica.com at 04/26/2023 07:14:24AM via free access 


\section{Results}

Plasma FFA concentrations were greater in the IH and $\mathrm{IH}+\mathrm{PBA}$ groups compared to the control groups (SAL and PBA) during the basal and clamp steady states $(P<0.05$, Fig. 1A). Basal insulin concentrations were similar across treatment groups and the infusion of insulin induced the same extent of hyperinsulinemia (Fig. 1B).

There were no statistically significant differences between treatment groups in basal endogenous glucose production (EGP) (Fig. 1C). During hyperinsulinemia, EGP was significantly higher in the IH group compared to the other groups $(P<0.05)$ and comparable between $\mathrm{IH}+\mathrm{PBA}$, SAL, and PBA alone groups (Fig. 1C). The suppression of EGP by insulin, expressed as a percentage of basal EGP, was diminished by IH infusion, and PBA co-infusion partially prevented this impairment (Fig. 1D). Insulin-stimulated glucose utilization was diminished by $\mathrm{IH}$ administration $(P<0.05$, Fig. 1E), but PBA co-infusion prevented the IH-induced peripheral insulin resistance. Accordingly, PBA co-infusion prevented whole-body insulin resistance caused by IH infusion, as indicated by the increased glucose infusion rate during the clamp steady state (Fig. 1F). The extent of insulin-stimulated activation of Akt, which is a marker of insulin sensitivity, was determined in the liver and skeletal muscle. In the liver, IH decreased insulinstimulated activation of Akt (p-Akt/total Akt) and PBA partially prevented this effect (Fig. 2A), consistent with the partial restoration of insulin-induced suppression of EGP. There were no significant differences in p-Akt/total Akt in skeletal muscle (Fig. 2B), likely because the magnitude of insulin resistance caused by IH was lower in the periphery than in the liver.

We then determined whether prolonged elevation in plasma FFAs affected ER stress markers in the liver and if PBA has the potential to reverse it. IH did not increase the extent of hepatic phosphorylation of eukaryotic initiation factor- $2 \alpha$ (p-eIF2 $\alpha$ ) (Fig. 3A). Moreover, liver mRNA levels of GRP78 were surprisingly decreased by IH $(P<0.05$, Fig. 3B), and hepatic GRP78 protein content was similar between groups (Fig. 3C). However, in adipose tissue, IH infusion augmented p-eIF $2 \alpha$ protein levels and this was prevented by PBA $(P<0.05$, Fig. $4 A)$. Inositol requiring $1 \alpha$ (IRE1 $\alpha$ ) showed a similar profile to p-eIF $2 \alpha$; however, there was no statistical significance across groups (Fig. 4C). GRP78 mRNA levels were elevated by IH and normalized by PBA $(P<0.05$; Fig. 4D), although GRP78 protein content, which is a more relevant marker of ER stress than GRP78 mRNA, was not significantly different across groups (Fig. 4B).
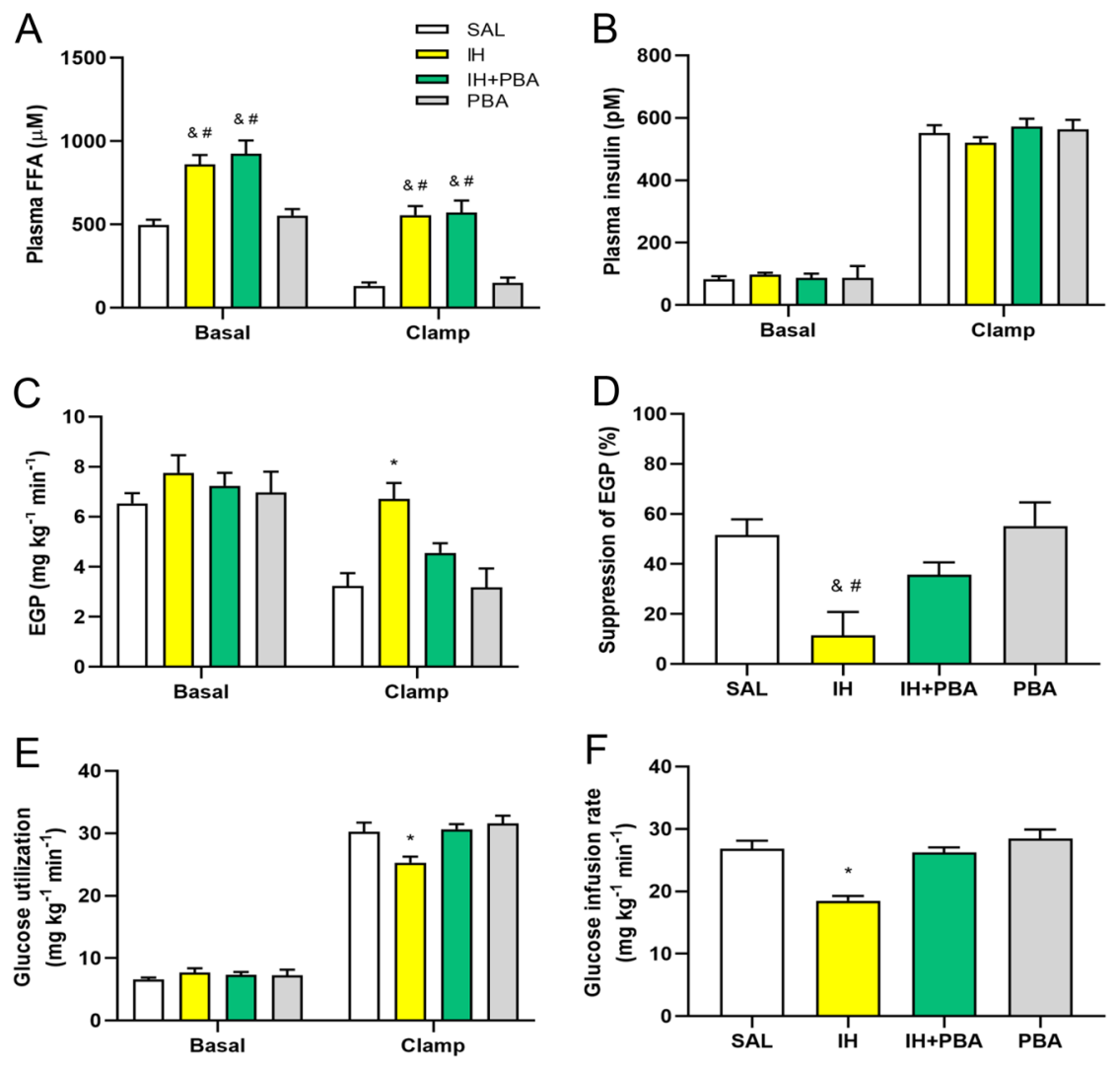

Figure 1

(A) Plasma free fatty acids (FFAs) and (B) plasma insulin during basal and clamp periods.

(C) Endogenous glucose production (EGP) in the basal and clamp periods, (D) percent suppression in EGP by insulin, (E) glucose utilization in the basal and clamp periods, and (F) glucose infusion rate during the clamp period. Treatments: SAL, saline; $I \mathrm{H}$, intralipid plus heparin; $I \mathrm{H}+\mathrm{PBA}, \mathrm{IH}$ plus 4-phenylbutyric acid; PBA, 4-phenylbutyric acid. $n=9$ for SAL; $n=6$ for $\mathrm{IH} ; n=8$ for $\mathrm{IH}+\mathrm{PBA} ; n=5$ for PBA. $* P<0.05$ vs other groups. ${ }^{\&} P<0.05$ vs SAL. ${ }^{\#} P<0.05$ vs PBA. In (A), (B), (C), and (E) there is a clamp (hyperinsulinemic) main effect $(P<0.05)$. 
A

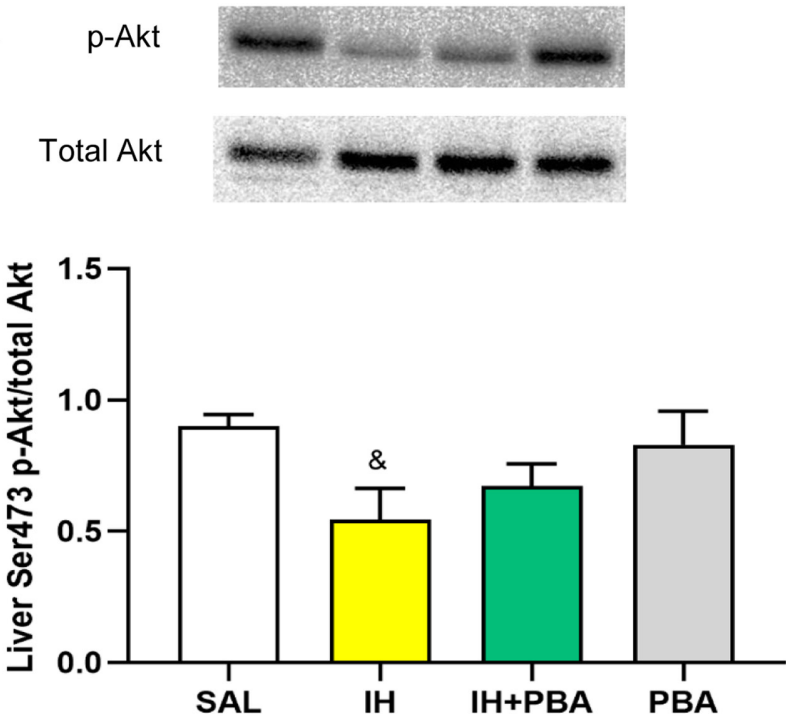

B
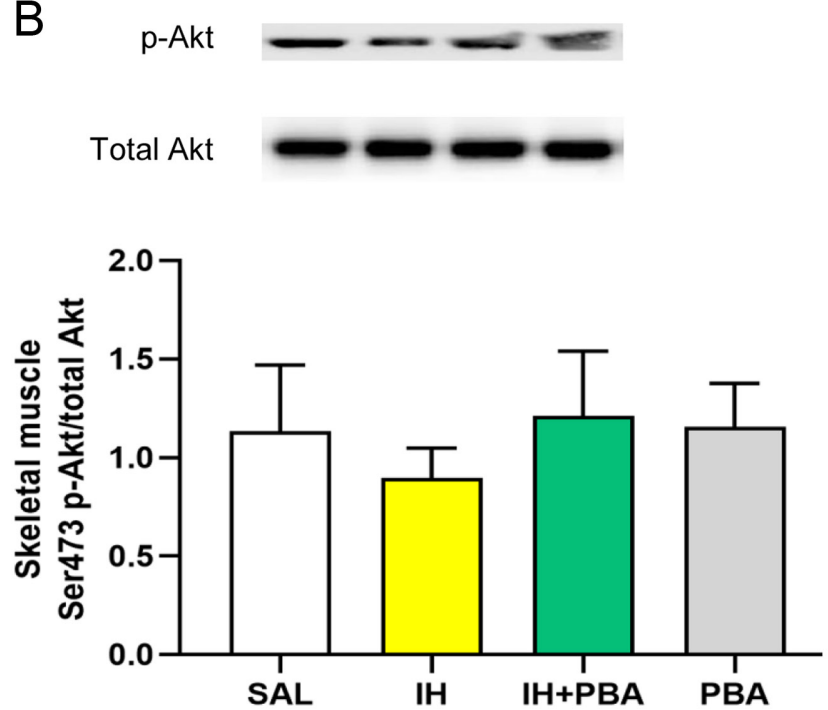

Figure 2

(A) Liver Ser473 phosphorylated Akt divided by total Akt. $n=7$ for SAL; $n=5$ for $\mathrm{IH} ; n=7$ for IH+PBA; $n=4$ for PBA. (B) Skeletal muscle Ser473 phosphorylated Akt divided by total Akt. $n=4$ for SAL; $n=5$ for $\mathrm{IH} ; n=5$ for IH+PBA; $n=5$ for PBA. Treatments: SAL, saline; IH, intralipid plus heparin; IH+PBA, IH plus 4-phenylbutyric acid; PBA, 4-phenylbutyric acid. $\& P<0.05$ VS SAL.

Hepatic insulin sensitivity can be altered by circulating cytokines and therefore, we determined plasma concentrations of cytokines, specifically IL-6, fetuin-A, and FGF21. These three cytokines can be expressed by adipose tissue $(19,20,21)$, but plasma levels of FGF21 are largely derived from the liver (22). In rodents fed with high-fat diet, hepatic insulin resistance can be mediated by IL-6 secreted from adipose tissue (23). Fetuin-A is a ligand of toll-like receptor 4 (TLR4) and has been implicated in FFA activation of TLR4 and insulin resistance (24).
A p-elF $2 \alpha$

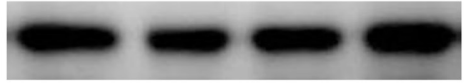

Actin
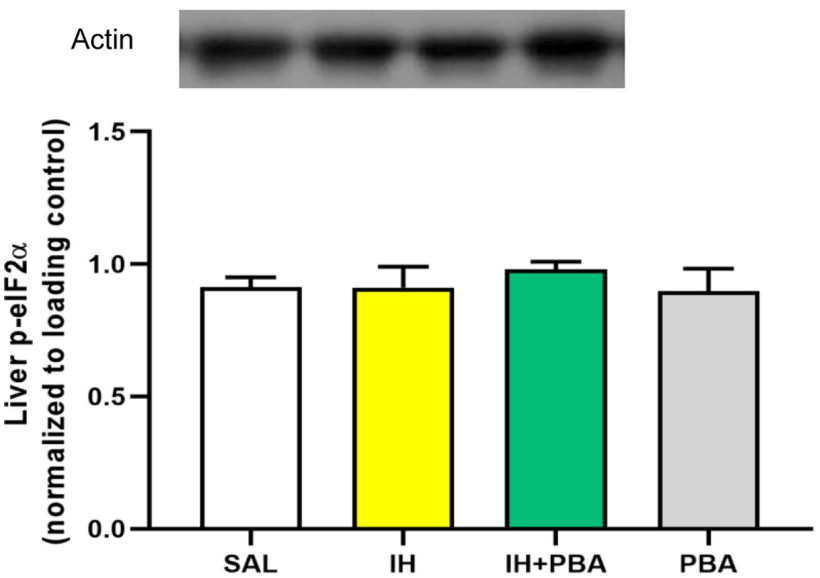

B

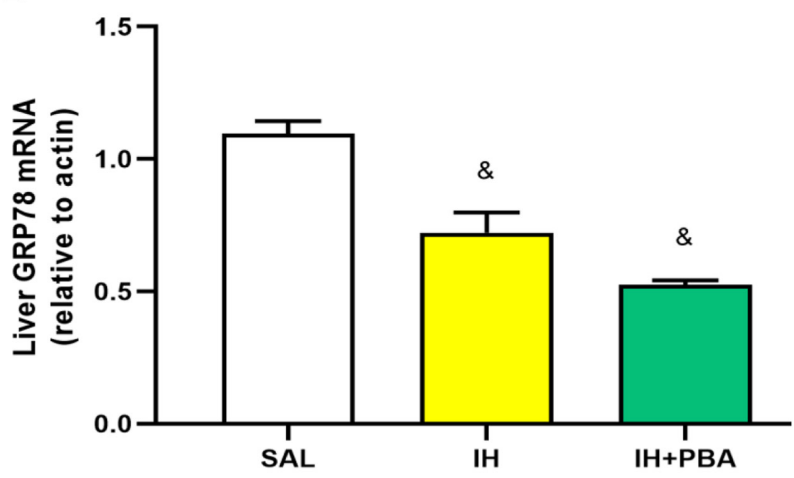

C
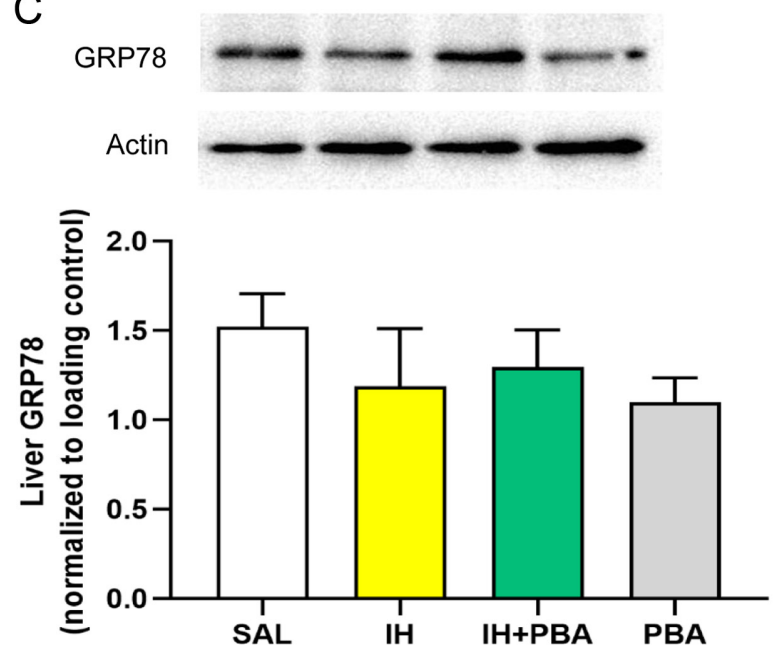

Figure 3

(A) Phosphorylated elF2 $\alpha$ protein content normalized to loading control in the liver. $n=6$ for SAL; $n=6$ for IH; $n=6$ for IH+PBA; $n=4$ for PBA. (B) GRP78 mRNA levels in the liver ( $n=3$ /group). (C) GRP78 protein content normalized to loading control in the liver. $n=8$ for SAL; $n=5$ for $\mathrm{IH} ; n=7$ for $\mathrm{IH}+\mathrm{PBA}$; $n=4$ for PBA. Treatments: SAL, saline; IH, intralipid plus heparin; IH+PBA, IH plus 4-phenylbutyric acid; PBA, 4-phenylbutyric acid. ${ }^{\circledR} P<0.05$ vs SAL. 

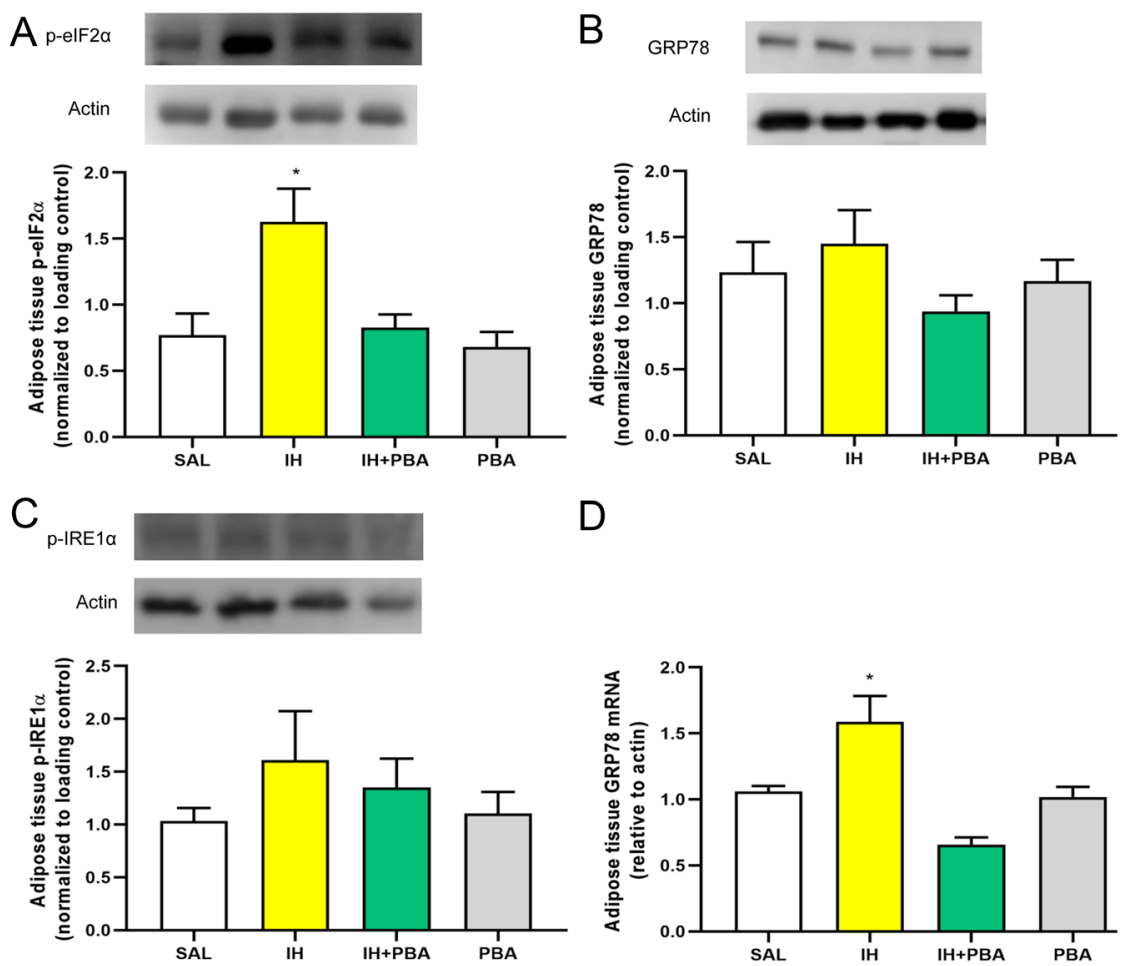

D

\section{Figure 4}

(A) Phosphorylated elF2 $\alpha$ protein content normalized to loading control in adipose tissue. $n=4$ for SAL; $n=4$ for $\mathrm{IH} ; n=6$ for $\mathrm{IH}+\mathrm{PBA} ; n=3$ for PBA. (B) GRP78 protein content normalized to loading control in adipose tissue. $n=6$ for SAL; $n=4$ for $\mathrm{IH} ; n=5$ for $\mathrm{IH}+\mathrm{PBA} ; n=3$ for PBA. (C) Phosphorylated IRE1 $\alpha$ protein content normalized to loading control in adipose tissue. $n=5$ for SAL; $n=3$ for $\mathrm{IH} ; n=7$ for $\mathrm{IH}+\mathrm{PBA} ; n=3$ for PBA. (D) GRP78 mRNA levels in adipose tissue. $n=3$ /group. Treatments: SAL, saline; $\mathrm{IH}$, intralipid plus heparin; $I \mathrm{H}+\mathrm{PBA}, \mathrm{IH}$ plus 4-phenylbutyric acid; PBA, 4-phenylbutyric acid. ${ }^{*} P<0.05$ vs other groups.
Fetuin-A can also interfere with insulin receptor signaling directly (25). Conversely, hepatic insulin resistance is diminished by FGF21 in rodents exposed to nutrient excess (26), and FGF21 can activate Akt via its own signaling (27). Plasma IL-6 concentrations were similar across treatment groups (Fig. 5A). Although differences in plasma fetuin-A concentrations between groups did not reach statistical significance, there was a trend for plasma fetuin-A to be lower in the IH+PBA group vs SAL and IH groups $(P=0.146$ and $P=0.060$, respectively; Fig. 5B). Plasma concentrations of FGF21 were higher in IH+PBA and PBA groups compared to the SAL group $(P<0.05)$ and there was a trend for FGF21 to be higher in $\mathrm{IH}+\mathrm{PBA}$ and $\mathrm{PBA}$ groups vs the $\mathrm{IH}$ group $(P=0.178$ and $P=0.124$, respectively; Fig. $5 \mathrm{C})$. We also assessed IL-6, fetuin-A, and FGF21 gene expression in the adipose tissue and liver. Differences in adipose tissue IL-6 mRNA levels across treatments did not reach statistical significance (Fig. 6A), but in the liver, IH robustly increased IL-6 mRNA $(P<0.05)$ and PBA co-infusion diminished this effect (Fig. 6B). IL-6 increases the gene expression of SOCS3, which impairs insulin signaling at the level of insulin receptor substrate (IRS) proteins $(28,29)$. However, in our study, hepatic SOCS3 protein content was not altered by either IH or PBA (Fig. 6C). Fetuin-A gene expression was lowest in the IH+PBA group without reaching statistical significance in adipose tissue (Fig. 7A); it was significantly lower in $\mathrm{IH}, \mathrm{IH}+\mathrm{PBA}$, and PBA groups vs SAL in the liver $(P<0.05$; Fig. 7B). Adipose tissue FGF21 mRNA levels were higher in the PBA group compared to the IH+PBA group $(\mathrm{p}<0.05$; Fig. $8 \mathrm{~A})$, while in the liver, there was a tendency for FGF21 gene expression in the PBA groups to be higher vs the IH group ( $P=0.112$ for PBA; Fig. 8B), consistent with the elevated FGF21 plasma levels in PBA-treated groups (Fig. 5C). Quantification of FGF21 protein content indicated that FGF21 expression was greater in the IH+PBA group in adipose tissue $(P<0.05$ vs SAL), but not in the liver (Fig. 8Cand D). In skeletal muscle, FGF21 mRNA levels were not significantly different among groups (Fig. 8E).

Improvement of hepatic insulin sensitivity by FGF21 has been reported to be associated with diminished PKC- $\varepsilon$ activationin theliver(26). Wepreviouslyfound thathepatic PKC- $\varepsilon$ is not affected by $7 \mathrm{~h} \mathrm{IH} \mathrm{(30)} \mathrm{or} 48 \mathrm{~h}$ IH (unpublished) infusion; however, PKC- $\delta$, another novel PKC isoform, is activated by $48 \mathrm{~h}$ IH infusion (13) and mediates hepatic insulin resistance caused by $7 \mathrm{~h}$ IH infusion (30). Hence, we assessed whether PBA affected IH-induced hepatic PKC- $\delta$ activation, based on the extent of PKC- $\delta$ translocation to the membrane from the cytosol (13). We found that IH infusion increased $\mathrm{PKC}-\delta$ protein content in the membrane fraction, which was not prevented by PBA co-infusion (Fig. 9A). Next, we assessed hepatic lipid accumulation because novel PKCs such
This work is licensed under a Creative Commons Attribution-NonCommercial 4.0 International License. ded from Bioscientifica.com at 04/26/2023 07:14:24AM 

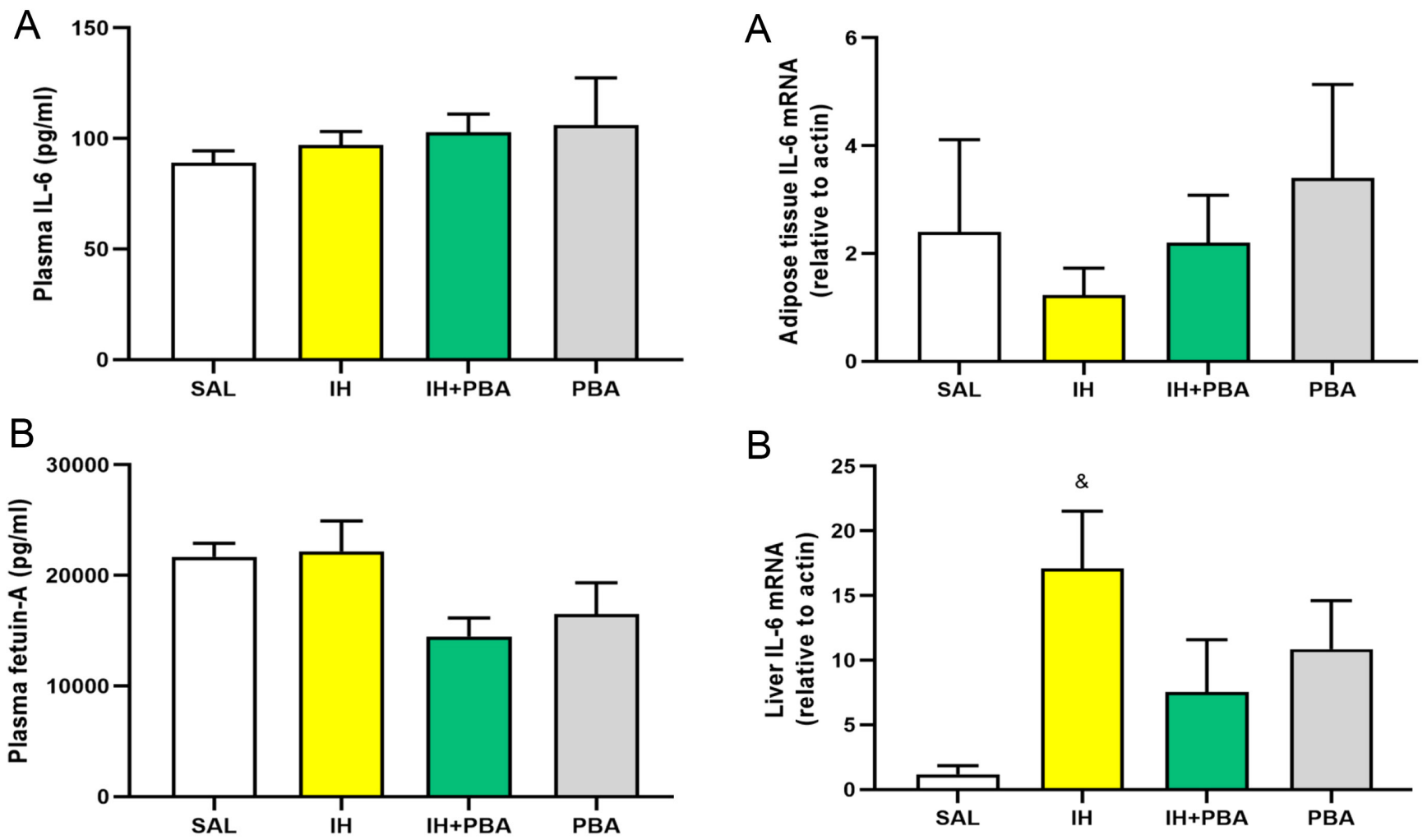

B
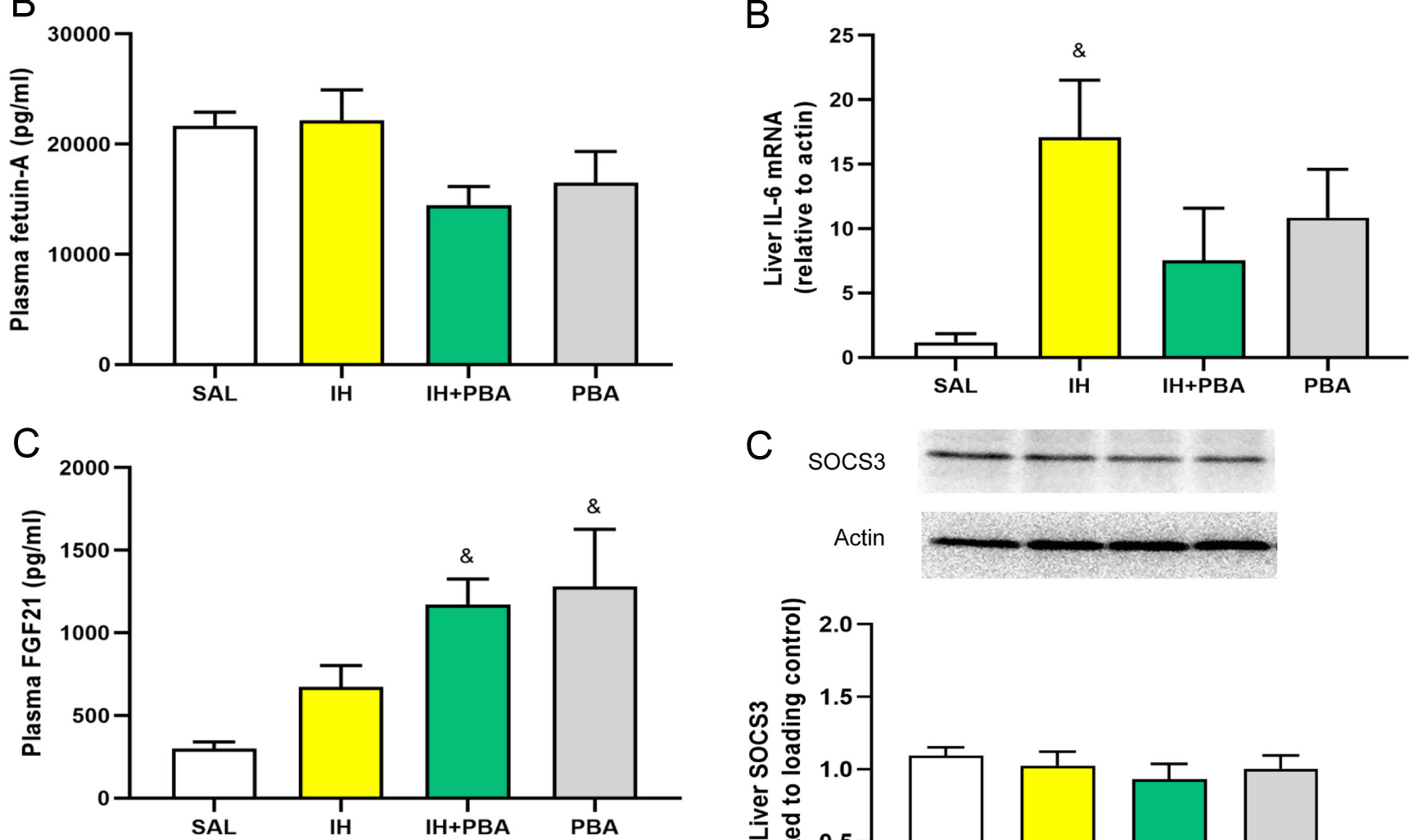

Figure 5

(A) Plasma IL-6 concentration. $n=10$ for SAL; $n=12$ for IH; $n=13$ for $\mathrm{IH}+\mathrm{PBA} ; n=8$ for PBA. (B) Plasma fetuin-A concentration. $n=7$ for SAL; $n=10$ for $\mathrm{IH} ; n=14$ for IH+PBA; $n=9$ for PBA. (C) Plasma FGF21 concentration. $n=10$ for SAL; $n=12$ for $\mathrm{IH} ; n=14$ for $\mathrm{IH}+\mathrm{PBA} ; n=9$ for PBA. Treatments: SAL, saline; IH, intralipid plus heparin; IH+PBA, IH plus 4-phenylbutyric acid; PBA, 4-phenylbutyric acid. \& $P<0.05$ vs SAL.

as PKC- $\delta$ are activated by diacylglycerol (DAG) (31). Quantification of Oil Red $O$ staining indicated that IH-infused groups had a similar approximately twofold increase in fat accumulation vs SAL, although statistical significance was not achieved (Fig. 9B). Thus, PBA did not decrease intrahepatic fat. Lastly, since we previously found that a p38 MAPK inhibitor prevents hepatic insulin resistance caused by $48 \mathrm{~h}$ IH infusion

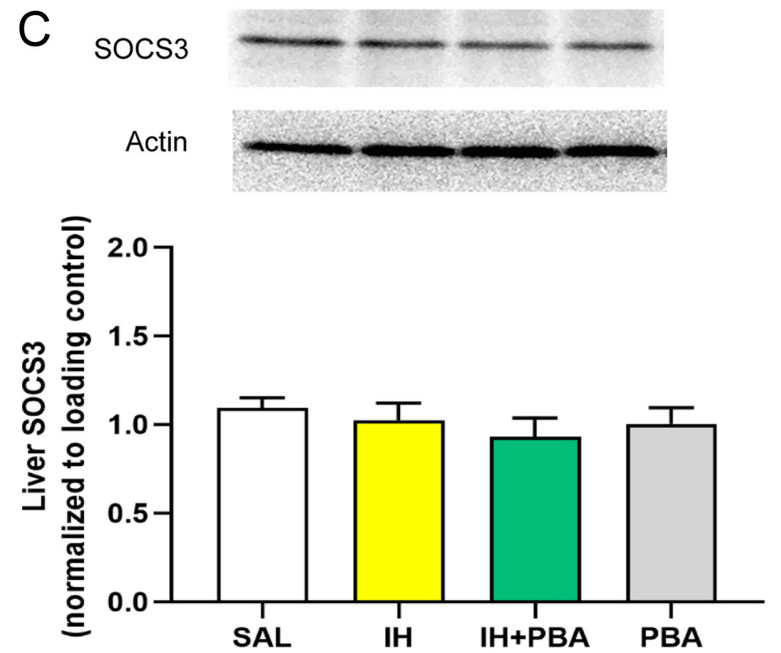

Figure 6

(A) Adipose tissue IL-6 mRNA levels. $n=3$ /group. (B) Hepatic IL-6 mRNA levels. $n=4$ /group. (C) Hepatic SOCS3 protein content normalized to loading control. $n=4$ /group. Samples used for these experiments were collected after $48 \mathrm{~h}$ basal infusion studies. Treatments: SAL, saline; $\mathrm{IH}$, intralipid plus heparin; IH+PBA, IH plus 4-phenylbutyric acid; PBA, 4-phenylbutyric acid. ${ }^{\circledR} P<0.05$ vs SAL.

(32), we assessed two markers of p38 MAPK activation in the liver: phosphorylated ATF2/ATF7 as well as the total ATF2/ATF7 (p38 MAPK decreases degradation of ATF2 (33)). PBA did not alter these hepatic markers of p38 MAPK activation (Fig. 10).

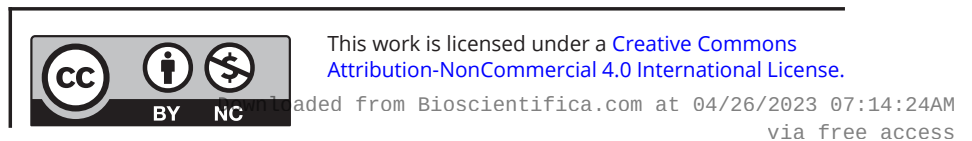


A
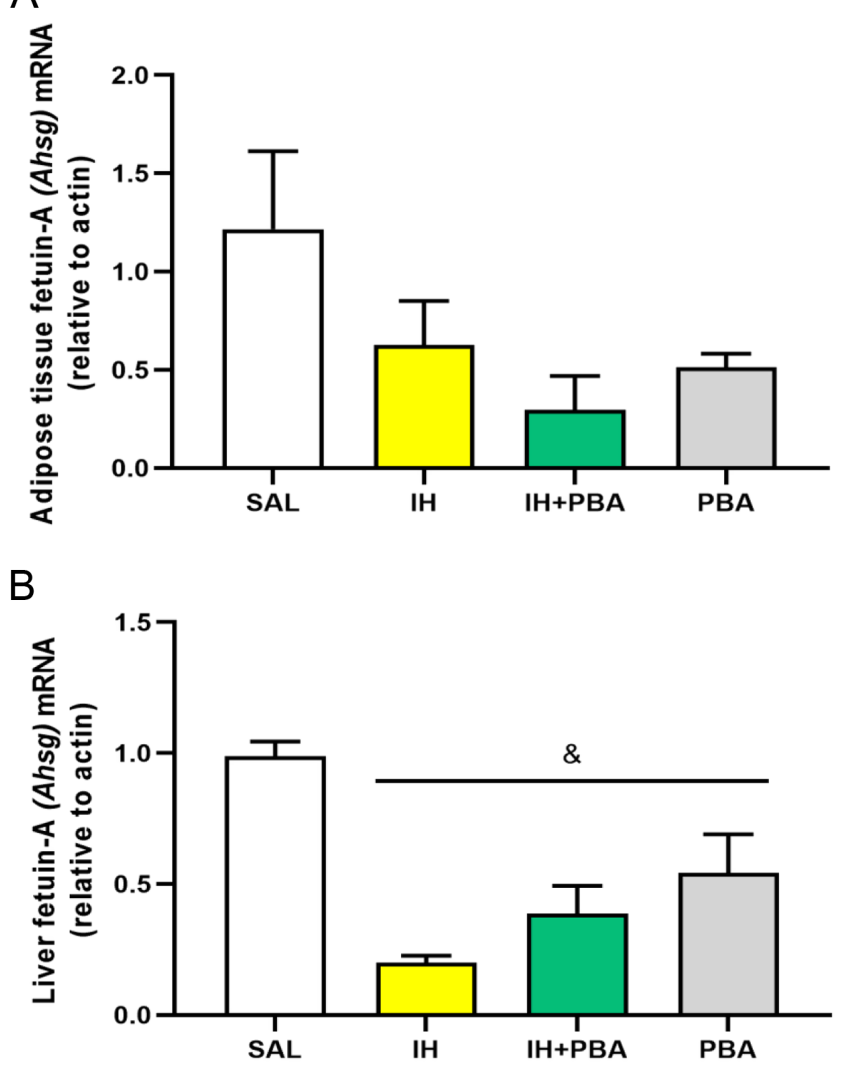

Figure 7

(A) Adipose tissue fetuin-A (Ahsg) mRNA levels. $n=3$ for SAL; $n=4$ for $\mathrm{IH}$; $n=3$ for IH+PBA; $n=4$ for PBA. (B) Hepatic fetuin-A (Ahsg) mRNA levels. $n=4$ /group. Treatments: SAL, saline; $I H$, intralipid plus heparin; IH+PBA, IH plus 4-phenylbutyric acid; PBA, 4-phenylbutyric acid. ${ }^{~} P<0.05$ vs SAL.

\section{Discussion}

The chemical chaperone PBA is a Food and Drug Administration (FDA)-approved drug that acts to assist protein folding resulting in alleviation of ER stress. In the present study, we examined its effect on IH-induced insulin resistance. In our $48 \mathrm{~h}$ IH infusion model in rats, we found that the ability of PBA to alleviate IH-induced hepatic insulin resistance occurs independently of changes in ER stress markers in the liver. This by itself is novel information and extends the indications for PBA to models where ER stress is absent. Instead, our findings suggest that prolonged IH infusion elevates some markers of ER stress in adipose tissue, which is prevented by PBA co-administration. Our study also demonstrates that PBA has pleiotropic effects on tissues and circulating factors, which have not been sufficiently appreciated in the literature. Circulating levels of IL- 6 and fetuin-A were not significantly affected by either IH or PBA, although there was a trend for fetuin-A to be lower in the co-infusion group. PBA augmented the concentration of plasma FGF21, presumably derived from the liver (22). PBA was able to prevent IH-induced peripheral insulin resistance; however, ER stress markers are generally not elevated in muscle in models of obesity $(3,9)$. In our previous studies in this $48 \mathrm{~h}$ IH infusion model, an antioxidant and IKK $\beta$ inhibitor also prevented IH-induced peripheral insulin resistance $(12,13)$, and therefore, PBA may have acted as an antioxidant or anti-inflammatory agent in addition to the effect of FGF21, which itself has antioxidant and anti-inflammatory properties $(34,35)$. However, antioxidant and anti-inflammatory agents, which prevent hepatic insulin resistance after $7 \mathrm{~h} \mathrm{IH}$ infusion $(30,36)$, did not prevent hepatic insulin resistance previously in this model $(12,13)$, suggesting hepatic adaptation to $48 \mathrm{~h} \mathrm{IH}$ infusion.

The use of chemical chaperones such as PBA and TUDCA to treat obesity-associated insulin resistance is an attractive therapeutic strategy because they are effective and are already approved for clinical use in the treatment of other disorders such as urea cycle disorders and cholestatic liver disease, respectively $(9,10)$. In the current study, PBA alleviated IH-induced ER stress in adipose tissue but IH did not induce ER stress in the liver. The absence of induction of ER stress markers in the liver was unexpected, given the effect of oleate infusion to increase hepatic ER markers in mice (6). Besides species differences, it may be explained by the mild physiological elevation of plasma FFAs, by its limited duration compared to the chronic diet studies (where ER stress is also dependent on diet duration $(3,37,38,39))$, and by the type of lipid emulsion infused. Intralipid is mostly $\omega-6$ unsaturated fat and hepatic ER stress has been most consistently associated with saturated fat (38).

IL-6 derived from adipose tissue can cause hepatic insulin resistance (23); however, IL-6 gene expression was not elevated in adipose tissue, and plasma IL-6 concentrations were not affected by IH. We found that IH increased hepatic IL-6 mRNA levels, which were reduced by PBA co-infusion. IL- 6 can dampen insulin signaling at the level of IRS proteins by increasing SOCS3 expression $(28,29)$. Nevertheless, the IL-6-SOCS3 pathway is unlikely to cause hepatic insulin resistance in our study because the hepatic protein content of SOCS3 was similar across groups. In addition, markers of IKK $\beta$ and c-jun $\mathrm{NH}_{2}$ terminal kinase (JNK) activity are not elevated in this model $(13,32)$. Another causal agent of insulin resistance is fetuin-A, which mediates activation of TLR4 by fatty acids (24) and can affect insulin signaling directly (25). We found a trend for PBA co-infusion to decrease circulating

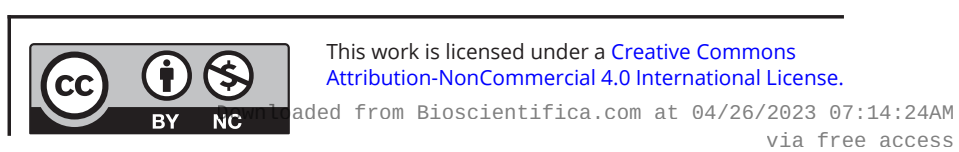


A

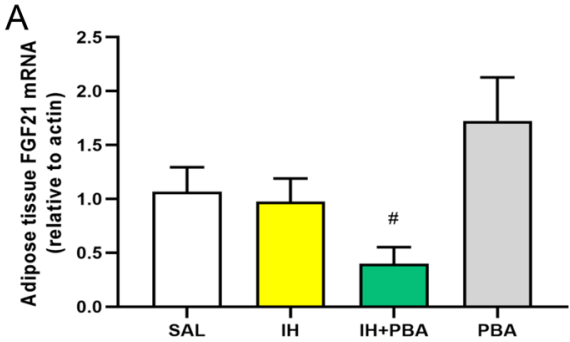

C
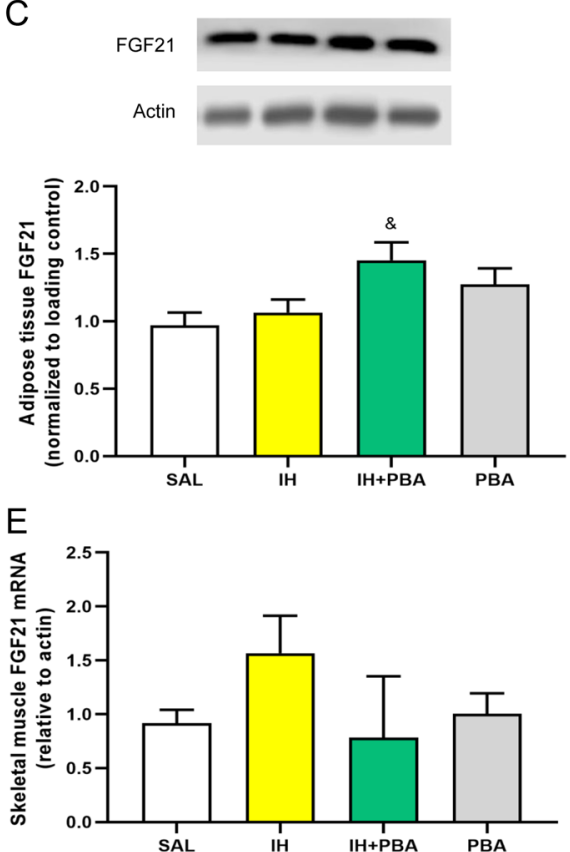

B

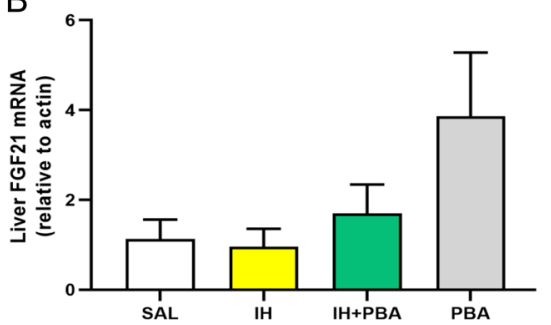

D FGF21 Actin

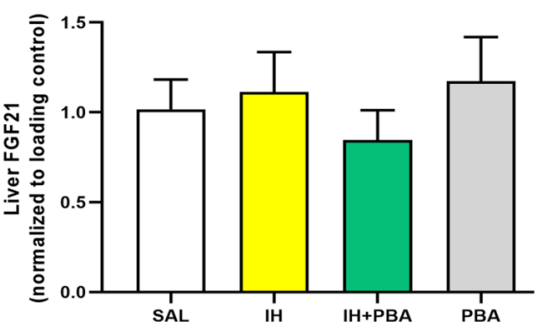

Figure 8

(A) Adipose tissue FGF21 mRNA levels. $n=3$ for $\mathrm{SAL} ; n=4$ for $\mathrm{IH} ; n=3$ for $\mathrm{IH}+\mathrm{PBA} ; n=3$ for PBA. (B) Hepatic FGF21 mRNA levels. $n=4$ /group. (C) FGF21 protein content normalized to loading control in adipose tissue. $n=5$ for SAL; $n=6$ for $\mathrm{IH} ; n=7$ for $\mathrm{IH}+\mathrm{PBA} ; n=5$ for PBA. (D) FGF21 protein content normalized to loading control in the liver. $n=6$ for SAL; $n=5$ for $\mathrm{IH} ; n=6$ for $\mathrm{IH}+\mathrm{PBA} ; n=4$ for PBA. (E) Skeletal muscle FGF21 mRNA levels. $n=4$ for SAL; $n=4$ for $\mathrm{IH} ; n=3$ for $\mathrm{IH}+\mathrm{PBA} ; n=4$ for PBA. Treatments: SAL, saline; $\mathrm{IH}$, intralipid plus heparin; IH+PBA, IH plus 4-phenylbutyric acid; PBA, 4-phenylbutyric acid. $\& p<0.05$ vs SAL. ${ }^{*} P<0.05$ vs PBA.
fetuin-A relative to the IH group. PBA has been reported to decrease the expression of fetuin-A in the liver (40). In our study, liver fetuin gene expression was not further reduced by PBA relative to IH. In adipose tissue, fetuin-A gene expression was reduced approximately by half in the IH+PBA group vs the IH group, although statistical significance was not achieved. Thus, we cannot rule out that PBA may decrease circulating fetuin-A by relieving ER stress in adipose tissue, and decreased circulating fetuin-A could alleviate in part IH-induced hepatic insulin resistance, likely via synergizing with FGF21 to increase Akt activity. The decrease in fetuin-A gene expression by IH alone despite the induction of ER stress could be due to the high content of anti-inflammatory $\omega-3$ fatty acids in IH.

PBA elevated plasma concentration of FGF21, which likely originated from the liver because although PBA increased protein content of FGF21 in adipose tissue, adipose-derived FGF21 has been shown to act in an autocrine manner (41). In contrast, the liver is the major source for circulating FGF21 (22) and despite the finding that PBA did not significantly alter hepatic FGF21 mRNA or protein levels, it is likely that newly translated FGF21 is immediately secreted. We observed an approximately four-fold elevation in circulating FGF21 in the IH+PBA group vs the SAL group and Camporez et al. (26) reported that an approximately four-fold elevation in circulating FGF21 ameliorated hepatic and peripheral insulin resistance caused by high-fat diet. These effects of FGF21 were associated with diminished hepatic activation of PKC- $\varepsilon$, a novel PKC isoform, and reduced triglyceride and DAG content in the liver (26). In our IH infusion model, PKC- $\delta$, but not PKC- $\varepsilon$, is the novel PKC isoform which is activated. PBA co-infusion, however, did not prevent activation of PKC- $\delta$ by IH and it did not reduce hepatic lipid accumulation. We previously reported that a p38 MAPK inhibitor can prevent hepatic insulin resistance induced by $48 \mathrm{~h} \mathrm{IH}$ administration (32) and Dollet et al. (42) showed that FGF21 can inhibit p38 MAPK, but in the current study PBA did not decrease markers of p38 MAPK activation in the liver. Interestingly, in human adipocytes, 
A

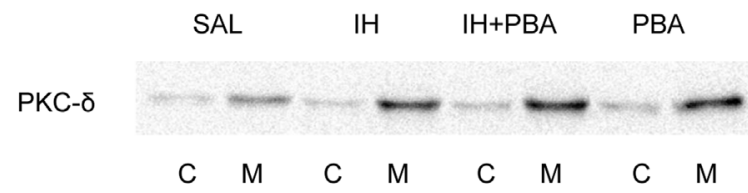

政

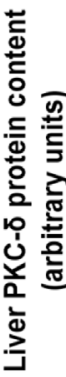

25000

20000

15000

10000

5000

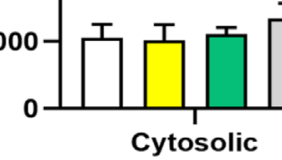

B

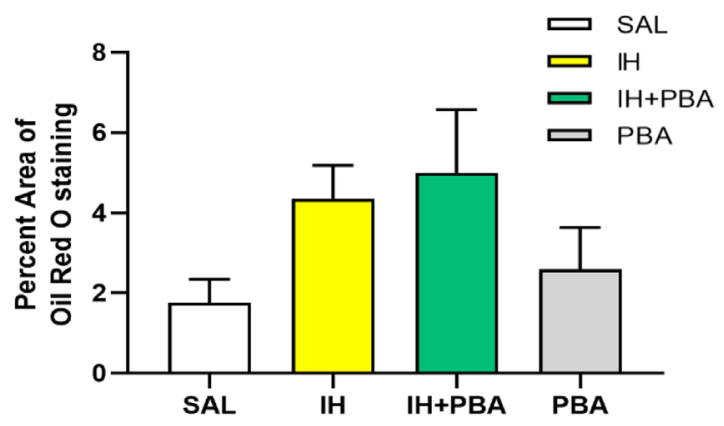

Figure 9

(A) Hepatic PKC- $\delta$ protein content in cytosolic (C) and membrane (M) fractions. $n=5$ for SAL; $n=5$ for $\mathrm{IH} ; n=5$ for $\mathrm{IH}+\mathrm{PBA} ; n=4$ for PBA. (B) Quantification of Oil Red O staining in liver samples. $n=4$ for SAL; $n=4$ for $\mathrm{IH} ; n=5$ for IH+PBA; $n=4$ for PBA. Treatments: SAL, saline; $\mathrm{IH}$, intralipid plus heparin; IH+PBA, IH plus 4-phenylbutyric acid; PBA, 4-phenylbutyric acid. ${ }^{\&} P<0.05$ vs SAL.

FGF21 stimulates the insulin signaling pathway at the level of Akt (27). Hence, in our study, the improvement in in vivo hepatic insulin sensitivity and in hepatic Akt activation resulting from PBA co-infusion may be due to FGF21 engaging its receptor in the liver. This action, similar to the possible action of low fetuin-A, could be independent of the action of IH but could only be manifest under conditions of low Akt activity, regardless of the cause.

The question then arises about how PBA could increase FGF21. In addition to being a chemical chaperone, PBA can also act as a histone deacetylase (HDAC) inhibitor (11). It has been reported to increase FGF21 mRNA via inhibition of HDAC2 and HDAC3 (43), which are class I HDACs (44). Although PBA can affect the transcription of gluconeogenic enzymes by inhibiting HDACs $(8,45)$, this is unlikely to be the main mechanism in our studies because basal EGP was not affected by PBA, whereas PBA improved glucose production suppression during the clamp (i.e. increased the action of insulin in suppressing EGP).

Our study has a few limitations. We used an i.v. lipid infusion model to more selectively mimic the elevation in plasma FFAs observed in obesity compared to high-fat diet-fed models, as in our previous study in humans (10). However, i.v. lipid infusion models are less chronic than high-fat diet models. Moreover, non-toxic lipid infusions such as intralipid contain a large amount of $\omega-6$ PUFAs and anti-inflammatory $\omega$-3 PUFAs, which do not reproduce the physiological composition of plasma FFA.

In conclusion, the results of the current paper indicate that PBA prevents FFA-induced hepatic insulin resistance in vivo, independent of hepatic ER stress. The PBA effect to improve hepatic insulin sensitivity is likely due to direct Akt stimulation by FGF21, perhaps in concert with decreased fetuin-A. Improving hepatic insulin sensitivity is important therapeutically, as the liver plays a dominant role in the pathogenesis of hyperglycemia.
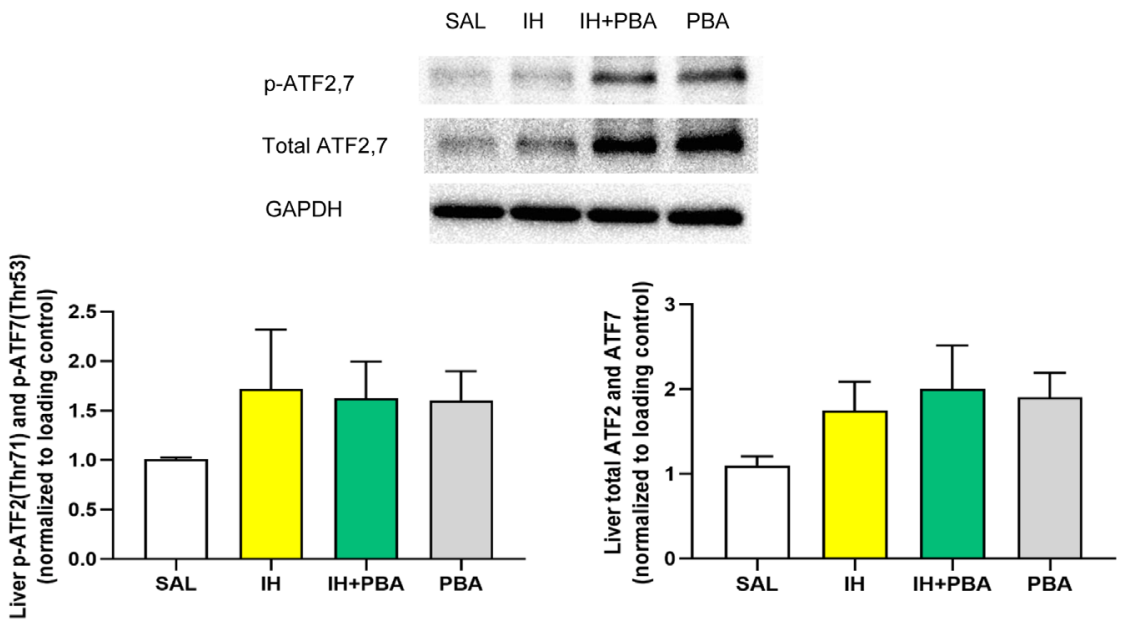

Figure 10

Liver Thr71 phosphorylated ATF2 and Thr53 phosphorylated ATF7 as well as total liver ATF2 and ATF7 protein content normalized to loading control. $n=4$ /group. Samples used for these experiments were collected after $48 \mathrm{~h}$ basal infusion studies Treatments: SAL, saline; IH, intralipid plus heparin; IH+PBA, $\mathrm{IH}$ plus 4-phenylbutyric acid; PBA, 4-phenylbutyric acid.

https://ec.bioscientifica.com https://doi.org/10.1530/EC-21-0248 (c) 2021 The authors Published by Bioscientifica Ltd

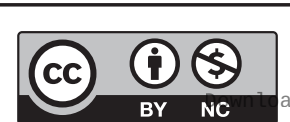

This work is licensed under a Creative Commons Attribution-NonCommercial 4.0 International License. ded from Bioscientifica.com at 04/26/2023 07:14:24AM via free access 


\section{Declaration of interest}

The authors declare that there is no conflict of interest that could be perceived as prejudicing the impartiality of the research reported.

\section{Funding}

This study was funded by research grants to A G from the Canadian Institutes of Health Research (CIHR) (MOP-89929 and PJT-153032). S P was supported by a Canada Graduate Scholarships Doctoral Award from CIHR, an Ontario Graduate Scholarship (OGS), a Banting and Best Diabetes center (BBDC)/Novo Nordisk Studentship, and a BBDC Trainee Travel Award. W Q Y was supported by an OGS, a BBDC Trainee Travel Award, and a School of Graduate Studies Conference Grant.

\section{Acknowledgements}

The authors thank Loretta Lam for outstanding technical expertise and the Toronto Center for Phenogenomics for Oil Red O staining. The authors would like to thank Liling Zhang, technician to Dr Volchuk, who has been removed from the author list as neither the co-authors, nor Endocrine Connections, were able to contact her to approve the manuscript.

\section{References}

1 Lewis GF, Carpentier A, Adeli K \& Giacca A. Disordered fat storage and mobilization in the pathogenesis of insulin resistance and type 2 diabetes. Endocrine Reviews 200223 201-229. (https://doi.org/10.1210/ edrv.23.2.0461)

2 Tripathy D, Mohanty P, Dhindsa S, Syed T, Ghanim H, Aljada A \& Dandona P. Elevation of free fatty acids induces inflammation and impairs vascular reactivity in healthy subjects. Diabetes 200352 2882-2887. (https://doi.org/10.2337/diabetes.52.12.2882)

3 Ozcan U, Cao Q, Yilmaz E, Lee AH, Iwakoshi NN, Ozdelen E, Tuncman G, Gorgun C, Glimcher LH \& Hotamisligil GS. Endoplasmic reticulum stress links obesity, insulin action, and type 2 diabetes. Science 2004306 457-461. (https://doi.org/10.1126/science.1103160)

4 Zhang K \& Kaufman RJ. From endoplasmic-reticulum stress to the inflammatory response. Nature $2008 \mathbf{4 5 4} 455-462$. (https://doi. org/10.1038/nature07203)

5 Pfaffenbach KT, Gentile CL, Nivala AM, Wang D, Wei Y \& Pagliassotti MJ. Linking endoplasmic reticulum stress to cell death in hepatocytes: roles of C/EBP homologous protein and chemical chaperones in palmitate-mediated cell death. American Journal of Physiology: Endocrinology and Metabolism 2010298 E1027-E1035. (https://doi.org/10.1152/ajpendo.00642.2009)

6 Ota T, Gayet C \& Ginsberg HN. Inhibition of apolipoprotein B100 secretion by lipid-induced hepatic endoplasmic reticulum stress in rodents. Journal of Clinical Investigation 2008118 316-332. (https://doi. org/10.1172/JCI32752)

7 Ozcan U, Yilmaz E, Ozcan L, Furuhashi M, Vaillancourt E, Smith RO, Gorgun CZ \& Hotamisligil GS. Chemical chaperones reduce ER stress and restore glucose homeostasis in a mouse model of type 2 diabetes. Science 2006313 1137-1140. (https://doi.org/10.1126/science.1128294)

8 Kimura K, Yamada T, Matsumoto M, Kido Y, Hosooka T, Asahara S, Matsuda T, Ota T, Watanabe H, Sai Y, et al. Endoplasmic reticulum stress inhibits STAT3-dependent suppression of hepatic gluconeogenesis via dephosphorylation and deacetylation. Diabetes 201261 61-73. (https://doi.org/10.2337/db10-1684)

9 Kars M, Yang L, Gregor MF, Mohammed BS, Pietka TA, Finck BN, Patterson BW, Horton JD, Mittendorfer B, Hotamisligil GS, et al. Tauroursodeoxycholic acid may improve liver and muscle but not adipose tissue insulin sensitivity in obese men and women. Diabetes 201059 1899-1905. (https://doi.org/10.2337/db10-0308)
10 Xiao C, Giacca A \& Lewis GF. Sodium phenylbutyrate, a drug with known capacity to reduce endoplasmic reticulum stress, partially alleviates lipid-induced insulin resistance and beta-cell dysfunction in humans. Diabetes 201160 918-924. (https://doi.org/10.2337/db101433)

11 Kusaczuk M, Kretowski R, Bartoszewicz M \& Cechowska-Pasko M. Phenylbutyrate-a pan-HDAC inhibitor-suppresses proliferation of glioblastoma LN-229 cell line. Tumour Biology 201637 931-942. (https://doi.org/10.1007/s13277-015-3781-8)

12 Pereira S, Shah A, George Fantus I, Joseph JW \& Giacca A. Effect of $\mathrm{N}$-acetyl-1-cysteine on insulin resistance caused by prolonged free fatty acid elevation. Journal of Endocrinology 2015225 1-7. (https://doi. org/10.1530/JOE-14-0676)

13 Pereira S, Yu WQ, Frigolet ME, Beaudry JL, Shpilberg Y, Park E, Dirlea C, Nyomba BL, Riddell MC, Fantus IG, et al. Duration of rise in free fatty acids determines salicylate's effect on hepatic insulin sensitivity. Journal of Endocrinology 2013217 31-43. (https://doi.org/10.1530/JOE12-0214)

14 Tang C, Naassan AE, Chamson-Reig A, Koulajian K, Goh TT, Yoon F, Oprescu AI, Ghanim H, Lewis GF, Dandona P, et al. Susceptibility to fatty acid-induced beta-cell dysfunction is enhanced in prediabetic diabetes-prone biobreeding rats: a potential link between beta-cell lipotoxicity and islet inflammation. Endocrinology 2013 154 89-101. (https://doi.org/10.1210/en.2012-1720)

15 Zhang L, Lai E, Teodoro T \& Volchuk A. GRP78, but not proteindisulfide isomerase, partially reverses hyperglycemia-induced inhibition of insulin synthesis and secretion in pancreatic beta-cells. Journal of Biological Chemistry 2009284 5289-5298. (https://doi. org/10.1074/jbc.M805477200)

16 Moore J, Megaly M, MacNeil AJ, Klentrou P \& Tsiani E. Rosemary extract reduces Akt/mTOR/p70S6K activation and inhibits proliferation and survival of A549 human lung cancer cells. Biomedicine and Pharmacotherapy 201683 725-732. (https://doi. org/10.1016/j.biopha.2016.07.043)

17 Gozdecka M \& Breitwieser W. The roles of ATF2 (activating transcription factor 2) in tumorigenesis. Biochemical Society Transactions 201240 230-234. (https://doi.org/10.1042/ BST20110630)

18 Patel R, Patel M, Tsai R, Lin V, Bookout AL, Zhang Y, Magomedova L, Li T, Chan JF, Budd C, et al. LXRbeta is required for glucocorticoidinduced hyperglycemia and hepatosteatosis in mice. Journal of Clinical Investigation 2011 121 431-441. (https://doi.org/10.1172/JCI41681)

19 Chatterjee P, Seal S, Mukherjee S, Kundu R, Mukherjee S, Ray S, Mukhopadhyay S, Majumdar SS \& Bhattacharya S. Adipocyte fetuin-A contributes to macrophage migration into adipose tissue and polarization of macrophages. Journal of Biological Chemistry $201328 \mathbf{8}$ 28324-28330. (https://doi.org/10.1074/jbc.C113.495473)

20 Zhang W, Mottillo EP, Zhao J, Gartung A, VanHecke GC, Lee JF, Maddipati KR, Xu H, Ahn YH, Proia RL, et al. Adipocyte lipolysisstimulated interleukin- 6 production requires sphingosine kinase 1 activity. Journal of Biological Chemistry 2014289 32178-32185. (https:// doi.org/10.1074/jbc.M114.601096)

21 Gomez-Samano MÁ, Grajales-Gomez M, Zuarth-Vazquez JM, NavarroFlores MF, Martinez-Saavedra M, Juarez-Leon ÓA, Morales-Garcia MG, Enriquez-Estrada VM, Gomez-Perez FJ \& Cuevas-Ramos D. Fibroblast growth factor 21 and its novel association with oxidative stress. Redox Biology 201711 335-341. (https://doi.org/10.1016/j.redox.2016.12.024)

22 Markan KR, Naber MC, Ameka MK, Anderegg MD, Mangelsdorf DJ, Kliewer SA, Mohammadi M \& Potthoff MJ. Circulating FGF21 is liver derived and enhances glucose uptake during refeeding and overfeeding. Diabetes 201463 4057-4063. (https://doi.org/10.2337/ db14-0595)

23 Sabio G, Das M, Mora A, Zhang Z, Jun JY, Ko HJ, Barrett T, Kim JK \& Davis RJ. A stress signaling pathway in adipose tissue regulates hepatic insulin resistance. Science 2008322 1539-1543. (https://doi. org/10.1126/science.1160794)

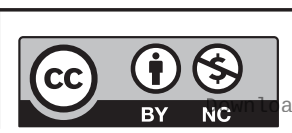

This work is licensed under a Creative Commons Attribution-NonCommercial 4.0 International License. ded from Bioscientifica.com at 04/26/2023 07:14:24AM 


\section{$10: 8$}

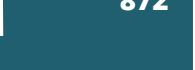

24 Pal D, Dasgupta S, Kundu R, Maitra S, Das G, Mukhopadhyay S, Ray S, Majumdar SS \& Bhattacharya S. Fetuin-A acts as an endogenous ligand of TLR4 to promote lipid-induced insulin resistance. Nature Medicine 201218 1279-1285. (https://doi.org/10.1038/nm.2851)

25 Srinivas PR, Wagner AS, Reddy LV, Deutsch DD, Leon MA, Goustin AS \& Grunberger G. Serum alpha 2-HS-glycoprotein is an inhibitor of the human insulin receptor at the tyrosine kinase level. Molecular Endocrinology 19937 1445-1455. (https://doi.org/10.1210/ mend.7.11.7906861)

26 Camporez JP, Jornayvaz FR, Petersen MC, Pesta D, Guigni BA, Serr J, Zhang D, Kahn M, Samuel VT, Jurczak MJ, et al. Cellular mechanisms by which FGF21 improves insulin sensitivity in male mice. Endocrinology 2013 154 3099-3109. (https://doi.org/10.1210/en.2013-1191)

27 Lee DV, Li D, Yan Q, Zhu Y, Goodwin B, Calle R, Brenner MB \& Talukdar S. Fibroblast growth factor 21 improves insulin sensitivity and synergizes with insulin in human adipose stem cell-derived (hASC) adipocytes. PLoS ONE 20149 e111767. (https://doi.org/10.1371/ journal.pone.0111767)

28 Starr R, Willson TA, Viney EM, Murray LJ, Rayner JR, Jenkins BJ, Gonda TJ, Alexander WS, Metcalf D, Nicola NA, et al. A family of cytokine-inducible inhibitors of signalling. Nature 1997 387 917-921. (https://doi.org/10.1038/43206)

29 Ueki K, Kondo T \& Kahn CR. Suppressor of cytokine signaling 1 (SOCS-1) and SOCS-3 cause insulin resistance through inhibition of tyrosine phosphorylation of insulin receptor substrate proteins by discrete mechanisms. [Erratum appears in Mol Cell Biol. 2005 Oct;25(19):8762]. Molecular and Cellular Biology 200424 5434-5446. (https://doi.org/10.1128/MCB.24.12.5434-5446.2004)

30 Pereira S, Park E, Mori Y, Haber CA, Han P, Uchida T, Stavar L, Oprescu AI, Koulajian K, Ivovic A, et al. FFA-induced hepatic insulin resistance in vivo is mediated by PKCdelta, NADPH oxidase, and oxidative stress. American Journal of Physiology: Endocrinology and Metabolism 2014307 E34-E46. (https://doi.org/10.1152/ ajpendo.00436.2013)

31 Kolczynska K, Loza-Valdes A, Hawro I \& Sumara G. Diacylglycerolevoked activation of PKC and PKD isoforms in regulation of glucose and lipid metabolism: a review. Lipids in Health and Disease 202019 113. (https://doi.org/10.1186/s12944-020-01286-8)

32 Pereira S, Yu WQ, Moore J, Mori Y, Tsiani E \& Giacca A. Effect of a p38 MAPK inhibitor on FFA-induced hepatic insulin resistance in vivo. Nutrition and Diabetes 20166 e210. (https://doi.org/10.1038/ nutd.2016.11)

33 Fuchs SY, Tappin I \& Ronai Z. Stability of the ATF2 transcription factor is regulated by phosphorylation and dephosphorylation. Journal of Biological Chemistry 2000275 12560-12564. (https://doi.org/10.1074/ jbc.275.17.12560)

$34 \mathrm{Kim}$ KH \& Lee MS. FGF21 as a mediator of adaptive responses to stress and metabolic benefits of anti-diabetic drugs. Journal of Endocrinology 2015226 R1-R16. (https://doi.org/10.1530/JOE-15-0160)
35 Zhang C, Shao M, Yang H, Chen L, Yu L, Cong W, Tian H, Zhang F, Cheng P, Jin L, et al. Attenuation of hyperlipidemia- and diabetesinduced early-stage apoptosis and late-stage renal dysfunction via administration of fibroblast growth factor- 21 is associated with suppression of renal inflammation. PLOS ONE 20138 e82275. (https:// doi.org/10.1371/journal.pone.0082275)

36 Park E, Wong V, Guan X, Oprescu AI \& Giacca A. Salicylate prevents hepatic insulin resistance caused by short-term elevation of free fatty acids in vivo. Journal of Endocrinology 2007195 323-331. (https://doi. org/10.1677/JOE-07-0005)

37 Ren LP, Chan SM, Zeng XY, Laybutt DR, Iseli TJ, Sun RQ, Kraegen EW, Cooney GJ, Turner N \& Ye JM. Differing endoplasmic reticulum stress response to excess lipogenesis versus lipid oversupply in relation to hepatic steatosis and insulin resistance. PLOS ONE 20127 e30816. (https://doi.org/10.1371/journal.pone.0030816)

38 Wang D, Wei Y \& Pagliassotti MJ. Saturated fatty acids promote endoplasmic reticulum stress and liver injury in rats with hepatic steatosis. Endocrinology 2006147 943-951. (https://doi.org/10.1210/ en.2005-0570)

39 Birkenfeld AL, Lee HY, Majumdar S, Jurczak MJ, Camporez JP, Jornayvaz FR, Frederick DW, Guigni B, Kahn M, Zhang D, et al. Influence of the hepatic eukaryotic initiation factor 2 alpha (eIF2alpha) endoplasmic reticulum (ER) stress response pathway on insulin-mediated ER stress and hepatic and peripheral glucose metabolism. Journal of Biological Chemistry 2011286 36163-36170. (https://doi.org/10.1074/jbc.M111.228817)

40 Ou HY, Wu HT, Hung HC, Yang YC, Wu JS \& Chang CJ. Endoplasmic reticulum stress induces the expression of fetuin-A to develop insulin resistance. Endocrinology 2012153 2974-2984. (https://doi. org/10.1210/en.2011-2043)

41 Dutchak PA, Katafuchi T, Bookout AL, Choi JH, Yu RT, Mangelsdorf DJ \& Kliewer SA. Fibroblast growth factor-21 regulates PPARgamma activity and the antidiabetic actions of thiazolidinediones. Cell 2012 148 556-567. (https://doi.org/10.1016/j.cell.2011.11.062)

42 Dollet L, Levrel C, Coskun T, Le Lay S, Le May C, Ayer A, Venara Q, Adams AC, Gimeno RE, Magre J, et al. FGF21 improves the adipocyte dysfunction related to seipin deficiency. Diabetes 201665 3410-3417. (https://doi.org/10.2337/db16-0327)

43 Leng Y, Wang J, Wang Z, Liao HM, Wei M, Leeds P \& Chuang DM. Valproic acid and other HDAC inhibitors upregulate FGF21 gene expression and promote process elongation in glia by inhibiting HDAC2 and 3. International Journal of Neuropsychopharmacology 2016 19 08. (https://doi.org/10.1093/ijnp/pyw035)

44 Seto E \& Yoshida M. Erasers of histone acetylation: the histone deacetylase enzymes. Cold Spring Harbor Perspectives in Biology 20146 a018713. (https://doi.org/10.1101/cshperspect.a018713)

45 Kouraklis G \& Theocharis S. Histone deacetylase inhibitors: a novel target of anticancer therapy (review) Oncology Reports 200615 489-494. (https://doi.org/10.3892/or.15.2.489)

Received in final form 21 May 2021

Accepted 9 July 2021

Accepted Manuscript published online 9 July 2021 https://ec.bioscientifica.com https://doi.org/10.1530/EC-21-0248
(C) 2021 The authors Published by Bioscientifica Ltd

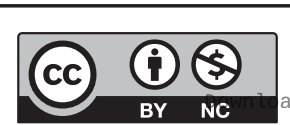

This work is licensed under a Creative Commons Attribution-NonCommercial 4.0 International License. ded from Bioscientifica.com at 04/26/2023 07:14:24AM 